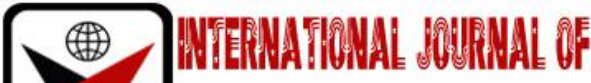

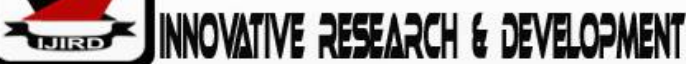

ISSN 2278-0211 (Online)

\section{Classroom Participation in EFL Speaking Classes: Students' Perceptions}

\author{
Thanh Nhan Thi Nguyen \\ Lecturer, Aston English Language Center, Can Tho City, Vietnam \\ Huan Buu Nguyen \\ Senior Lecturer, School of Foreign Languages, Can Tho University, Vietnam
}

\begin{abstract}
:
Although classroom participation has gained its increasing interest in influencing how students speak English as a foreign or second language, there still remains little research exploring this potential instructional practice in the Mekong Delta, Vietnam. This paper therefore considers students' perceptions about participation in speaking classes. Data collected in this descriptive study include questionnaire and interview. One hundred and four students participated in this study. The findings of this study reveal that students perceived oral participation at a high level. The paper concludes by presenting pedagogical implications and directions for further research.
\end{abstract}

Keywords: Perceptions, participation, discussion, speaking classes

\section{Introduction}

Research on classroom participation has undergone its growing changes over the past thirty years and recognized its benefits in assisting students in speaking English (Fassinger, 1995; Lyons, 1989; Rocca, 2010). Thus, active classroom participation plays an indispensable role in improving students' language learning and personal development(Tatar, 2005). In particular, the more student participation takes place, the better their learning and course content retention is likely to achieve. Or in other words, students are likely to foster their English language proficiency and speaking performance by actively participating classroom discussions. This influence may lead students to enhance their confidence while sharing, discussing, or evaluating different speaking topics in class or in front of other peers. However, students' oral participation is neglected because of their timidity, passivity, and fear of sharing ideas or opinions in front of the class, as indicated in the literature(Rocca, 2009, 2010; Weaver \& Qi, 2005). Also, at the context of the study, students were reported to lack motivation to learn English, interaction with their peers and teachers. For most parts of speaking milieu, students learned English merely because of passing the end-of the course or graduation examinations. In addition, students were unlikely to become aware of the importance of classroom participation while learning English as a foreign language. Despite the fact that recent studies in Vietnam addressed the factors influencing pair or group work activities, little research focuses on students' perceptions about participation in class discussions. Hence, this paper reported in this study fills this gap and seeks factors influencing their participation while implementing speaking activities.

\section{Literature Review}

\subsection{Theory of Student Involvement}

This study is based on Astin's (1984) theoretical framework of student involvement. Astin defines student involvement as 'the amount of physical and psychological energy that the student devotes to the academic experience'(p. 297). This theory suggests the notion of what students do instead of what they think, how they feel, and make sense of their practices (Harper \& Quaye, 2009). Student participation, willingness to make oral presentations, discussion, and role play are examples of such practice. In particular, highly involved students are likely to spend more time, energy, and efforts on completing their studies, participate actively in activities, and interact with others to achieve their desired goals (Astin, 1984, 1999). On the other hand, poorly involved students tend to neglect their studies, fail to focus on given assignments or interact with other peers or their teacher. Krause and Coates (2008)further advocate Astin's (1984)theory of involvement as they stress that student involvement is targeted at the quality of effort and energy that influences student learning at a desirable level. It is therefore student involvement in the learning process that characterizes behavioral aspect that promotes academic performance (Carini, Kuh, \& Klein, 2006), critical thinking (Garside, 1996; Gellin, 2003), learning outcomes (Pike, Kuh, \& Gonyea, 2003),and personal growth(Pascarella \& Terenzini, 2005). Taken altogether, the theory of student involvement confirms the trajectories of the interactive process of student learning, personal development, and the contextwhere they endeavor to attain their academic goals over time. 


\subsection{Speaking}

Speaking is key to students' oral language learning process and academic success(Bygate, 2010). It is viewed as an interactive process of constructing meaning (Cameron, 2001) and an effective way to communicate in English(Nunan, 1999). Given such importance, speaking allows students to interact, perform, and become competent as they use English. This productive skill is two-way communication that helps drive students to express ideas and feelings in a wide array of contexts. Others view speaking as a sophisticated process because it takes place in the real time either in terms of individuals' performance or ability (Koizumi, 2005). Another perspective is that speaking is a multifaceted construct involving accuracy and fluency (Ellis \& Barkhuizen, 2005; Skehan, 2009). While accuracy refers to the use of grammar, vocabulary, and pronunciation, fluency focuses on how to keep conversations going for effective communication (Nguyen \& Do, 2017). From the constructivist view, speaking provides students with an opportunity to communicate ideas with others dynamically and interactively.

\subsection{Classroom Participation}

Of different types of speaking activities such as pair and group work, presentation, interview, role play and classroom participation, participation is widely held as effective tool for enhancing students' speaking in English (Aziz, Quraishi, \& Kazi, 2018). There are several perspectives of classroom participation in the literature. However, a search of the relevant literature identifies three major views of classroom participation for this study. First, classroom participation literally refers to the way students ask or answer questions generated by the teacher or other peers (Mustapha, Rahman, \& Yunus, 2010; Weaver \& Qi, 2005). It implies an interactive process of communication that can facilitate student learning process. Second, classroom participation is defined as sharing opinions or experiences (Mustapha et al., 2010), for example, through making presentations. Third, participation is a learning process in which students discuss with others about a topic in speaking classes (Rocca, 2010). Through this spoken form, students come to know how to find solutions for this topic and learn how to express ideas effectively.

Drawn on these conceptualizations, classroom participation is defined, for the purposes of this study, as a communicative process in which students listen to others' ideas, initiate questions or responses and discuss a particular topic in apposite and interactive ways.

\subsection{Types of Classroom Participation}

Classroom participation is divided into two types: verbal and nonverbal (Abdullah et al., 2012). Verbal or oral participation refers to individual behaviors of asking and answering questions, sharing opinions or experiences, and giving comments. In contrast, nonverbal participation is associated with behaviors like nodding the head, raising hands, body movements, eye contact, and facial expressions. In this study, classroom participation is construed verbal.

\subsection{Benefits of Classroom Participation}

There is a growing recognition of the role classroom participation plays in helping students cultivate their learning process(e.g., Rocca, 2010). Therefore, once students are encouraged to participate in speaking or using English in their classes, they are likely to become more motivated and active while discussing, completing assignments, and gaining high levels of thinking. In particular, the more exposure of English usestudents are provided, the better their verbal English performance becomes. Another benefit is that classroom participation and students' academic achievement are intertwined (Delaney, 2012; Fritschner, 2000; Frymier \& Houser, 2016). The more students are involved in class activities, the better critical thinkers they become and the more confident they are (Garside, 1996; Precourt \& Gainor, 2018; Rocca, 2010). Garside (1996)further contends that active participation of students allows them to learn from others, reflect on their gains, and better their learning. Specifically, by taking part in class discussions, students can become capable of mastering their target language through spoken form. Active participation in class activities also provide students with an opportunity to improve their communication(Dancer \& Kamvounias, 2005), interaction, and preparedness for class and self-regulated learning in the learning process (Rocca, 2010; Sidelinger \& Booth-Butterfield, 2010).

\subsection{Factors That Influence Classroom Participation}

Several studies have addressed some factors influencing student participation in class activities. Class size, seating arrangements, timing, course type, and fear of face-losing, to name a few are examples of dominant determinants of students' verbal participation(Berdine, 1986; Rocca, 2010).

Berdine (1986) notes that students are likely not to participate in a larger class (more than 25) than in smaller ones. A review of student participation in the college classroom by Rocca (2010)reported that students in a class of over 35 students had few interactions per class period and that students in a class of ten or few students reported more participation than those in a class of forty or more. It is possible that students in smaller classes were given more opportunities to discuss or communicate.

Seating arrangement is the second factor that affects how student participate in class activities(McCroskey \& McVetta, 1978). These authors contend that there are three most common ways of seating in a class: traditional, horseshoe, and modular; and that each can have its own function and is conducive to student participation. Also, there is a correlation between seat arrangement and interaction. Traditional arrangement is assumed to ease teacher-student interaction while the horseshoe and modular or circular arrangement is observed to promote student-student and student-teacher interactions. Besides, if students are arranged to sit in a large circle, they tend to talk and interact more with each other and greater participation is obtained. In contrast, students are seated in traditional row and column seating participate less than those are in U-shaped or circular arrangement (Bowers, 1986; Rocca, 2010). However, it was 
found that seating preferences by arrangement and apprehension level are somehow connected in ways that students who have high apprehension tend to feel more anxious in circular seating (Neer \& Kircher, 1989).

Timing can be problematic for organizing effective participation, including class discussions (Bean \& Peterson, 1998; Howard, Short, \& Clark, 1996). Time of the day and week in the semester influence the amount of student participation and interaction. The total interaction and participation is likely to decrease if class meeting only takes place once per week. Of different parts of a day, only evening classes was found to be a source of interaction (Howard \& Henney, 1998). In addition, there is an increased participation of students as the semester progressed(Howard et al., 1996).

Other researchers have examined course type influencing student participation(Berdine, 1986; Crombie, Pyke, Silverthorn, Jones, \& Piccinin, 2003). According to these authors, students in arts and social sciences have a greater participation and talk for longer periods of time than those in natural sciences. In contrast, students in natural sciences tend to ask more questions and prefer lecturing, whereas students in humanities favor discussion format.

Students' fear of losing faces includes three factors: fear of making mistakes, fear of negative evaluation, and fear of peers' disapproval(Frisby, Berger, Burchett, Herovic, \& Strawser, 2014). Some students fear of making mistakes in front of their peers or the teacher because their incomplete responses to the teacher may leave negative impressions or comments by others (Berdine, 1986). This fear may hinder students' willingness to respond to questions raised by the teacher and other classmates (Mustapha et al., 2010).Fear of negative evaluation is related to students' unwillingness to participate in class activities(Neer \& Kircher, 1989). Students tend to feel ashamed of their poor performance perceived by peers.Fear of peers' disapproval can be explained in a situation which students interact within their own groups to construct learning under the formal authority and guidance of the teacher. Thus, these fears of losing faces related to individual identityare likely to influence students' behaviors, the amount of classroom participation, and their learning gains(Weaver \& Qi, 2005).

\subsection{Studies on Classroom Participation}

Recent studies have stressed the impact of students' perceptions about classroom participation to varying degrees on how Asian students learn English as a foreign or second language(Cao \& Philp, 2006; Lee, 2009; Mustapha et al., 2010). A qualitative research by Lee (2009) examined the factors influencing the oral classroom participation of six Korean students attending graduate school in the United States. The results from interview and class observations revealed that despite their beliefs in the importance of oral participation in their learning; they perceived the lack of English language proficiency, sociocultural differences, individual differences, and classroom environment as four factors that could impact effective discussions and interactions.

A study by Mustapha and her colleagues (2010) reported that in Malaysian classrooms, classroom participation was perceived by students as essential while communicating with the lecturer and other students in class through asking or answering questions, sharing opinions or experiences. They also considered participation as a commitment in the learning process through attendance, attention, and interest in class. Mustapha and colleagues(2010) further indicated a wide array of student reasons for not participating in discussion and differing views on classroom participation yielding a set of complexity that influences their participation practices. In particular, analysis from interviews and observation in two communication classes, factors were identified as age, gender, class size, student preparation, confidence, fear of losing face. In contrast, findings reveal that teacher-related traits, student-initiated aspects, class content, and physical settings influence student participation. Significantly, their study revealed that students considered the value of participation as this type of verbal performance could allow them to gain confidence, facilitate their learning, and become active participants.

A recent study conducted by Zhou (2015) investigating perceptions of the administrator, teachers and students on English language education at a Chinese university has indicated joint awareness of the critical role of classroom oral participation; however, there are variations of their perspectives of underlying issues with regard to the objectives of the English program and student learning gains. Participants in this study included four teachers and 104 first-year nonEnglish major undergraduates in the four English classes. The qualitative findings from the interviews suggest that although all stakeholders held positive attitudes towards the importance of classroom oral participation, students' perceptions of English program and oral participation were not valued by the teachers and administrator. Four themes identified as the program objectives, value of four English language skills, students' aspirations for English learning, and their interests in oral participation. Such differing views challenge students' oral participation in their learning process and also address the lesser role the teachers played to improve student learning, particularly their English communicative competence.

Another similar perspective can be seen in a study by Maddox (2015)who found that Saudi Arabian students recognized the role of active verbal participation in their academic life. Data collected in this study include surveys delivered to 65 students and interviewed conducted with seven students. The results from this study indicate the comfort levels with oral classroom participation and individual academic activities, focusing on group presentations, whole-class, small group, and discussions. However, interview data revealed the challenges encountered by students while making presentations and whole class discussions were linguistic proficiency (grammar, vocabulary, pronunciation) and personality factors (fear of losing face through mistake making, peer disapproval, or negative evaluation) respectively. These above studies suggest that despite the positive impact of classroom participation in English language learning, little research has been conducted with regard to students' perceptions about classroom participation in speaking classes at a university in Vietnam. This present study therefore fills the gap in the literature on classroom participation within the context where English is used as a foreign language. 


\section{Methodology}

A descriptive study using mixed-methods approach was conducted to examine students' perceptions about classroom participation in speaking classes. According to Fraenkel, Wallen and Hyun (2012), a mixed-methods approach incorporates quantitative and qualitative methods of data collection and analysis that allows for better understanding of the research problem under investigation than does the use of either form alone.

The design of the study included questionnaires and interviews. In this article, insights into students' perceptions about participation in whole class discussions in EFL speaking classes were obtained through quantitative approach using questionnaires with 104 students. A 30-item questionnaire was organized into four categories. The first category focuses on students' understanding of the meanings of classroom participation (CP) in speaking classes. The second category is aimed at exploring students' perceptions of the benefits of CP in speaking classes. The third category centers on challenges perceived by students while learning speaking. The four category enquires into the factors influencing students' participation in speaking classes. The pilot questionnaire was administered to 29 students and its reliability was confirmed with the Cronbach's alpha at .71. At the end of the study, to complement the quantitative data, semi-structured interviews were conducted with nine students individually to further examine theirviews of above-mentioned aspects of $\mathrm{CP}$ in speaking over a semester time. All the interview questions were designed in English and then translated into Vietnamese. The interviews were conducted in Vietnamese so that the participants felt more comfortable and could express all their ideas in a clear and natural way. Each interview took approximately half an hour.

The study reported in this article took place over a semester period during the academic year 2018-2019. The aim was to examine how classroom participationinfluences student learning in speaking and provide teachers with insightful views of finding out alternative ways to refine their teaching practices and students' speaking performance.

One hundred and four sophomores in English language studies and Interpretation and Translation at a university in the Mekong delta participated in the study. Their age range is from 19 to 22 (26 males, and 78 females). The rationale for this participant selection is on the convenience sampling basis(Fraenkel et al., 2012)because it focused on those who were available and willing to participate in this study. Of the total, on the basis of stratified sampling (Fraenkel et al., 2012), nine students from three classes were interviewed individually. In each class, three students using the criteria of one highachieving, one good-achieving, and one average were selected. Semi-structured interviews were used to gain insights into students' perceptions about classroom participation in speaking.

The quantitative data collected from the 30-item questionnaire were statistically analyzed using the SPSS (Statistical Package for the Social Sciences) version 20. All interview responses were recorded, transcribed, translated into English, and then organized using thematic analysis(Boyatzis, 1998).

\section{Findings}

\subsection{Findings from the Questionnaire}

\subsubsection{Students' Understanding of the Meanings of Classroom Participation}

The Descriptive Statistics test was used to examine students' understanding of classroom participation in speaking classes. The result of the test is presented in Table 1. Table 1 indicates that the mean score of students' understanding of classroom participation is at a high level $(M=4.24, S D=.22)$. AOne Sample $t$ - Test was computed to evaluate whether students' understanding is statistically different from the test value of 4.0, the accepted mean for high level. The result of the test, as indicated in Table 4.2,presents a significant difference ( $t=10.879, d f=103, p=.000)$. In particular, the most noticeable thing is that students conceptualized the value of participation in relation to their interest in learning from other peers at the highest level $(M=4.31, S D=.46)$, as shown in Table 4.3.

\begin{tabular}{|c|c|c|c|c|c|}
\hline & N & Min & Max & M & SD \\
\hline & 104 & 4.00 & 4.60 & 4.2404 & .22535 \\
\hline Valid N (listwise) & 104 & & & & \\
\hline
\end{tabular}

Table 1: Descriptive Statistics of Students' Understandings of Classroom Participation

\begin{tabular}{|c|c|c|c|c|c|c|}
\hline & $\mathbf{t}$ & df & Sig. & \multicolumn{2}{c|}{$\begin{array}{c}\text { Mean } \\
\text { difference }\end{array}$} & \multicolumn{2}{|c|}{$\begin{array}{c}\text { 95\% confidence interval of } \\
\text { the difference }\end{array}$} \\
\hline & & & & & Lower & Upper \\
\hline & 10.879 & 103 & .000 & .24038 & .1966 & .2842 \\
\hline
\end{tabular}

Table 2: One Sample t- Test of Students' Understanding Of Classroom Participation

\begin{tabular}{|ll|l|l|}
\hline Items & M & SD \\
\hline $1 . \quad$ Classroom participation is asking questions. & 4.11 & .32 \\
\hline $2 . \quad$ Classroom participation is answering questions. & 4.24 & .42 \\
\hline $3 . \quad$ Classroom participation is sharing opinions and experiences with other students. & 4.27 & .45 \\
\hline $\begin{array}{l}\text { 4. Classroom participation is discussing a particular topic with other students to find } \\
\text { solutions. }\end{array}$ & 4.25 & .43 \\
\hline $5 . \quad$ Classroom participation is a way to show interest and respect for other students' ideas. & 4.31 & .46 \\
\hline
\end{tabular}

Table 3: Students' Understanding of Classroom Participation (CP) 


\subsubsection{Students' Perceptions of the Benefits of Classroom Participation}

Section Two of the questionnaire consists of five items which correspond to students' perceptions of the benefits of classroom participation, as indicated in Table 4.4.

\begin{tabular}{|ll|c|c|}
\hline \multicolumn{1}{|c|}{ Items } & M & SD \\
\hline 6. & Classroom participation fosters students' speaking. & 4.44 & .49 \\
\hline 7. & Classroom participation improves students' listening. & 4.26 & .44 \\
\hline 8. & Classroom participation enhances students' academic achievement. & 4.41 & .49 \\
\hline 9. & Classroom participation allows students to become critical thinkers. & 4.69 & .46 \\
\hline 10. & Classroom participation makes students more confident. & 4.50 & .50 \\
\hline
\end{tabular}

Table 4: Descriptive Statistics of Students' Perceptions of the Benefits of CP

As can be seen from the descriptive statistics test, Table 4indicates that students perceived participation as enabling them to become critical thinkers at the highest level $(M=4.69, S D=.46)$, followed by their feeling of confidence $(M=4.50, S D=.50)$. While students thought participation could foster their speaking performance at high level $(M=4.44$, $S D=.49)$, and result in increased learning outcomes $(M=4.41, S D=.49)$., they had a little low sense of the benefit of listening yielded by participation $(M=4.26, S D=.44)$.

\subsubsection{Students' Perceptions of the Challenges of Classroom Participation}

Section Three of the questionnaire consisting of five items with regard to students' perceptions of the challenges of classroom participation was analyzed by using frequency test, as shown in Table 4.5.

\begin{tabular}{|l|l|l|l|}
\hline \multicolumn{1}{|c|}{$\mathbf{n = 1 0 4}$ Items } & \multicolumn{3}{c|}{ Frequencies (\%) } \\
\hline \multicolumn{1}{|c|}{ Good students usually dominate whole class discussions. } & \multicolumn{1}{|c|}{ SD\&D } & Neutral & SA\&A \\
\hline $11 . \quad$ There is a lack of time for students to participate in whole class & 18.3 & 6.7 & 62.5 \\
\hline $\begin{array}{l}12 . \\
\text { discussions. }\end{array}$ & 3.8 & 77.9 \\
\hline $13 . \quad$ Lots of ideas will lead to problems. & 26.9 & 22.1 & 51 \\
\hline $\begin{array}{l}14 . \quad \text { Encouraging all students to participatein whole class } \\
\text { discussions is not easy because of different learning styles. }\end{array}$ & 15.4 & 4.8 & 79.8 \\
\hline $\begin{array}{l}15 . \quad \text { A large space is a difficult condition for students to speak } \\
\text { loudly. }\end{array}$ & 18.3 & 16.3 & 65.4 \\
\hline
\end{tabular}

Table 5: Students' Perceptions of the Challenges of Classroom Participation

Note: SD \& D = Strongly Disagree \& Disagree; $N=$ Neutral; $S A \& A=$ Strongly Agree \& Agree

As can be seen in Table 4.5, the frequency for each item reveals students' perceptions about the challenges of classroom participation in discussions. Different learning styles was reported by more than three-fourths of students to be the most challenging thing that prevented them from participating in whole class discussions (79.8\%). Lack of time $(77.9 \%)$ and large space (65.4\%) were ranked the second and third challenges respectively. The fourth issue was that students thought good students usually dominate whole class discussions, thereby, hindering others from participating in speaking activities. The least barrier (51\%) perceived by students was that several ideas from peers would lead to other problems.

\subsection{Findings from the Interviews}

The interview data reveal that all of nine students perceived participation as an interactive process of contribution of ideas to discussion in different ways, including sharing information or ideas and asking or answering questions. In addition to benefits of this speaking activity, challenges are identified.

\subsubsection{Students' Views of Classroom Participation}

When asked to define 'participation' in class discussions, six students agreed that participation is sharing opinions and experiences with other peers about a topic. The examples of two students' views are presented below.

I think classroom participation is sharing my own ideas about a particular topic. (Hieu, interview extract)

When I stand up in front of class to present or share what I know about a given topic, I think it is a kind of classroom participation (Nghi, interview extract)

Three students agreed that classroom participation is answering questions. For instance, Thao said:

In whole class discussions, my teacher usually asks the whole class questions. Therefore, I think our responses are participation (Thao, interview extract)

In contrast, two participants believed that classroom participation is asking questions and that this activity involves interaction between the teacher and students, and among students. For example:

In my view, classroom participation is asking questions. I mean I ask my teacher if I don't understand the lesson well or I can ask my friends to make the whole class discussions more excitingly. (Nghi, interview extract)

When I am unsure of the lesson or subject content, I ask questions. Thus, students are participating in learning and understanding the lesson (Thy). 
Two other students believed that classroom participation is related to the notion of showing interest in and respect for other students' ideas. The following examples illustrate their views.

I personally suppose that classroom participation is listening to and respecting other ideas (Khanh, interview extract)

Well, to me, paying attention to others' questions or getting involved in responding to questions by the teacher or classmates is called as participation (Hung, interview extract).

\subsubsection{Conceptualizations on Benefits of Classroom Participation}

It was found that students' answers to the question what classroom participation benefits their learning were varied. The following extracts present a range of views that reflected their understanding of participation as a crucial part in their speaking class. Themes are identified as increased listening and pronunciation practice, feeling of confidence, communication, and critical thinking.

I think that the first benefit of classroom participation is the opportunity to practice pronunciation. If I have a pronunciation mistake on a word, the teacher corrects mine. The second is that, participation is what I can use new words while speaking. The third benefit is I feel more confident in talking with others. Thus, I also believe that after I graduate from the course, if I work in a foreign company, I will communicate with others better (Thao, interview extract)

In my opinion, classroom participation benefits me in two ways. Firstly, I can improve critical thinking. I know how to explain and defend my own ideas for a given topic of interest. If other ideas from my classmates are not logic and out of the topic, I will argue and present my own. Secondly, when I participate in class activities, the teacher shows me what mistakes I made in pronunciation of words or what structures should be considered (Hieu, interview extract) I personally think that I can enhance my listening skill when I take part in classroom activities. I can learn from listening to my friends and my teacher. That's what participation is (Phuc, interview extract)

\subsubsection{Challenges of Classroom Participation}

When asked what students thought about the challenges of classroom participation, all of the students revealed that time issue, space, and students' dominance over others were three challenges that prevented them from working with others in class discussions. The following examples illustrate their views.

I think there is not enough time for us to give answers or share opinions (Tan, interview extract)

In my own view, what makes us difficult to talk or here from other friends is the space in a large room. While discussions, I cannot hear my friends talking or sharing views because it is too noisy (Hieu, interview extract)

I personally think that sometimes good students dominate the talking time and talk much; and this leads to the fact that other students do not have an opportunity to ask or discuss over the lesson with other friends (Nhi, interview extract)

\section{Discussion}

The findings of the study indicate that the participating students perceived the importance of classroom participation in their speaking classes. In particular, these students acknowledged that participation could be beneficial in their learning process, with regard to increased listening and pronunciation practice, feeling of confidence, communication, and critical thinking. A possible reason could be that students were given the opportunity to have regular practice in discussions. Such positive benefits add on the literature on oral participation in several studies(e.g., Fassinger, 1995; Mustapha et al., 2010; Rocca, 2010) as these authors maintain that students' perceptions about participation are likely to impact upon students' behaviors, and as a result, these conceptualizations may impact their actual participation in relation to speaking performance.

Analysis from interview responses further suggests that asking or answering questions, sharing opinions and experiences with other students, showing interest in and respect for other students' ideas denote the interactive process of communication. This finding confirms Dancer and Kamvounias' (2005) claim that participation in speaking activities, namely discussions can allow students to learn more from their peers and enhance their oral communication skills.

It was found that classroom participation fosters students' speaking and listening. These findings are in line with those by Weaver and Qi (2005) and Delaney (2012). These authors contend thatactive participation of students in English as a second or foreign language (EFL) classes was proportional to their gains in language learning or proficiency. It is interesting to note that students perceived classroom participation as allowing them to become critical thinkers and confident learners. These findings act as evidence in the literature suggesting that students' participation in class activities has an important association with their level of confidence (Fassinger, 1996)as well as their critical thinking ability (Garside, 1996; Mustapha et al., 2010; Rocca, 2010).

Time for students to participate in whole class discussions, space, and students' dominance over others were identified as three challenges that prevented students from participation in speaking classes. This finding supports the claim of a study by Bean and Peterson (1998) as they indicate that lack of time is a disadvantage for organizing effective classroom discussions. A possible explanation may be that it took much time for teachers to manage speaking activities provided to students to share their own ideas or answer questions. A new finding is reported is the large space that hinders students' participation. Good students were reported to talk much during whole class discussions and this dominance could influence their peers in the learning process. As confirmed by Fritschner (2000), students learn best when they are actively or highly involved, thereby limiting others' chances to present ideas or discuss over a given topic. The study reinforces Astin's (1984) theory of student involvement in a way that there is a correlation between the amount of student involvement and their academic learning and experience. 


\section{Conclusions}

The findings from this present study provide insights into students' perceptions about classroom participation in discussions in their learning process. In light of these findings, some pedagogical implications are given. First, school administrators should limit the number of students in a speaking class because in some cases, a speaking class of forty to fifty students is not an exception and this causes difficulty for students in interacting with others. Second, the study may raise teachers' awareness of students' views towards oral participation as interactive and communicative process by considering how to select topics relevant to the needs and interests of students, arrange seating, and give extra credit to encourage greater participation or involvement in speaking. Another implication is that students should be given equal opportunities in verballing their ideas and opinions while speaking or discussing with others over a particular subject matter in a supportive learning milieu. Further research in a wider study into oral participation and other factors that may influence students' awareness of the importance of oral participation to allow them to take greater responsibility for their learning.

\section{References}

i. Astin, A. W. (1984). Student involvement: A developmental theory for higher education. Journal of College Student Personnel, 25(2), 297-308.

ii. Astin, A. W. (1999). Student involvement: A developmental theory for higher education. Developmental Theory, 40(5).

iii. Aziz, F., Quraishi, U., \& Kazi, A. S. (2018). Factors behind classroom participation of secondary school students (a gender based analysis). Universal Journal of Educational Research, 6(2), 211-217. doi: 10.13189/ujer.2018.060201

iv. Bean, J. C., \& Peterson, D. (1998). Grading classroom participation. New Directions for Teaching and Learning, 74, 33-40.

v. Berdine, R. (1986). Why some students fail to participate in class. Marketing News, 20, 23-24.

vi. Bowers, J. W. (1986). Classroom communication apprehension: A survey. Communication Education, 35, $372-378$.

vii. Boyatzis, R. E. (1998). Transforming qualitative information: Thematic analysis and code development Thousand Oaks, California: SAGE Publications, Inc.

viii. Brown, H. D. (2004). Language assessment: Principles and classroom practices (7th ed.): Longman.

ix. Bygate, M. (2010). Speaking (2nd Ed.). Oxford: Oxford University Press.

x. Cameron, L. (2001). Teaching languages to young learners. Cambridge: Cambridge University Press.

xi. Cao, Y., \& Philp, J. (2006). Interactional context and willingness to communicate: A comparison of behavior in whole class, group and dyadic interaction. System, 34(4), 480-493.

xii. Carini, R. M., Kuh, G. D., \& Klein, S. P. (2006). Student engagement and student learning: Testing the linkages. Research in Higher Education, 47(1), 1-32.

xiii. Crombie, G., Pyke, S. W., Silverthorn, N., Jones, A., \& Piccinin, S. (2003). Students' perceptions of their classroom participation and instructor as a function of gender and context. Journal of Higher Education, 74(1), 51-76.

xiv. Dancer, D., \& Kamvounias, P. (2005). Student involvement in assessment: A project designed to assess class participation fairly and reliably. Assessment and Evaluation in Higher Education, 30(4), 445-454.

xv. Delaney, T. (2012). Quality and quantity of oral participation and English proficiency gains. Language Teaching Research, 16(4), 467-482. doi: 10.1177/1362168812455586

xvi. Ellis, R., \& Barkhuizen, G. (2005). Analyzing learner language. Oxford: Oxford University Press.

xvii. Fassinger, P. A. (1995). Understanding classroom interaction. The Journal of Higher Education, 66(1), 82-96.

xviii. Fassinger, P. A. (1996). Professors' and students' perceptions of why student participate in class. Teaching Sociology, 24(1), 25-33. doi: https://doi.10.2307/1318895

xix. Fraenkel, J. R., Wallen, N. E., \& Hyun, H. H. (2012). How to design and evaluate research in education (8th Ed.). New York: McGraw-Hill Humanities.

xx. Frisby, B. N., Berger, E., Burchett, M., Herovic, E., \& Strawser, M. G. (2014). Participation apprehensive students: The influence of face support and instructor-student rapport on classroom participation. Communication Education, 63(2), 105-123. doi: https://doi.org/10.1080/03634523.2014.881516

xxi. Fritschner, L. M. (2000). Inside the undergraduate college classroom: Faculty and student differ on the meaning of student participation. The Journal of Higher Education, 71(3), 342-362.

xxii. Frymier, A. B., \& Houser, M. L. (2016). The role of oral participation in student engagement. Communication Education, 65(1), 83-104. doi: http:/dx.doi.org/10.1080/03634523.2015.1066019

xxiii. Garside, C. (1996). Look who's talking: A comparison of lecture and group discussion teaching strategies in developing critical thinking skills. Communication Education, 45(3), 212-227.

xxiv. Gellin, A. (2003). The effect of undergraduate student involvement on critical thinking: A meta-analysis of the literature 1991-2000. Journal of College Student Development, 44(6), 746-762.

xxv. Harper, S. R., \& Quaye, S. J. (2009). Student engagement in higher education: Theoretical perspectives and practical approaches for diverse populations. New York, NY: Routledge.

xxvi. Howard, J. R., \& Henney, A. L. (1998). Student participation and instructor gender in the mixed age college classroom. The Journal of Higher Education, 69(4), 384-405. doi: https://doi.org/10.1080/00221546.1998.11775141

xxvii. Howard, J. R., Short, L. B., \& Clark, S. M. (1996). Students' participation in the mixed age college classroom. Teaching Sociology, 24(1), 8-24. 
xxviii. Koizumi, R. (2005). Relationship between productive vocabulary knowledge and speaking performance of Japanese learners of English at the novice level. (PhD), University of Tsukuba, Japan.

xxix. Krause, K. L., \& Coates, H. (2008). Students' engagement in first-year university. Assessment and Evaluation in Higher Education, 33(5), 493-505.

xxx. Lee, G. (2009). Speaking up: Six Korean students' oral participation in class discussions in US graduate seminars. English for Specific Purposes, 28(3), 142-156. doi: https://doi.org/10.1016/j.esp.2009.01.007

xxxi. Lyons, P. R. (1989). Assessing classroom participation. College Teaching, 37, 36-38.

xxxii. Maddox, R. (2015). Saudi Arabian students' perceptions of oral classroom participation. (PhD), University of Cincinnati.

xxxiii. McCroskey, J. C., \& McVetta, R. W. (1978). Classroom seating arrangements: Instructional communication theory versus student preferences. Communication Education, 27(2), 99-111.

xxxiv. Mustapha, S. M., Rahman, N. S. N. A., \& Yunus, M. M. (2010). Perceptions towards classroom participation: A case study of Malaysian undergraduate students. Procedia Social and Behavioral Sciences, 7, 113-121. doi: 10.1016/j.sbspro.2010.10.017

xxxv. Neer, M. R., \& Kircher, W. F. (1989). Apprehensive' perception of classroom factors influencing their class participation. Communication Research Reports, 6(1), 70-77.

xxxvi. Nguyen, H. B., \& Do, N. N. T. (2017). Students' attitudes towards drama-based role play in freshmen's oral performance. European Journal of Foreign Language Teaching, 2(3), 30-48.

xxxvii. Nunan, D. (1999). Second language teaching and learning. Boston: Heinle \& Heinle Publishers.

xxxviii. Pascarella, E. T., \& Terenzini, P. T. (2005). How college affects students: A third decade of research. San Francisco: Jossey-Bass.

xxxix. Pike, G. R., Kuh, G. D., \& Gonyea, R. M. (2003). The relationship between institutional mission and students' involvement and educational outcomes. Research in Higher Education, 44(2), 241-261.

xl. Precourt, E., \& Gainor, M. (2018). Factors affecting classroom participation and how participation leads to a better learning. Accounting Education, 28(1), 100-118. doi: https://doi.org/10.1080/09639284.2018.1505530

xli. Rocca, K. A. (2009). Participation in the college classroom: The impact of instructor immediacy and verbal agression. The Journal of Classroom Interaction, 43(2), 22-33.

xlii. Rocca, K. A. (2010). Student participation in the college classroom: An extended multidisciplinary literature review. Communication Education, 59(2), 185-213. doi: doi.org/10.1080/03634520903505936

xliii. Sidelinger, R. J., \& Booth-Butterfield, M. (2010). Co-constructing student involvement: An examination of teacher confirmation and student-to-student connectedness in the college classroom. Communication Education, 59(2), 165-184. doi: https://doi.org/10.1080/03634520903390867

xliv. Skehan, P. (2009). Modeling second language performance: Integrating complexity, accuracy, fluency, and lexis. Applied Linguistics, 30(4), 510-532.

xlv. Tatar, S. (2005). Why keep slient? The classroom participation experiences of non-native English speaking students. Language and Intercultural Communication, 5(3), 284-293.

xlvi. Weaver, R. R., \& Qi, J. (2005). Classroom organization and participation: College students' perceptions. The Journal of Higher Education, 76(5), 570-601. doi: 10.1353/jhe.2005.0038

xlvii. Zhou, N. (2015). Oral participation in EFL classroom: Perspectives from the administrator, teachers and learners at a Chinese university. System, 53, 35-46. doi: http://dx.doi.org/10.1016/j.system.2015.06.007 